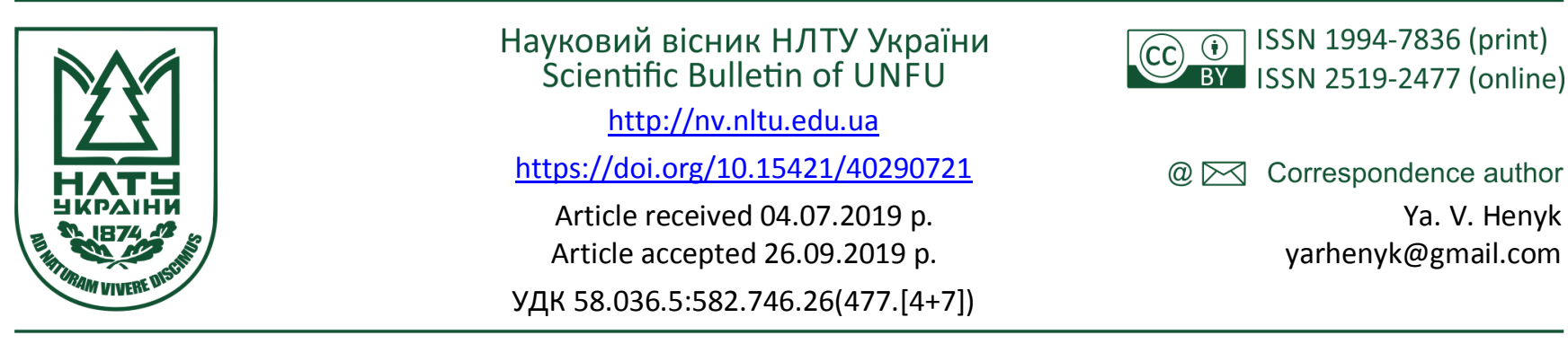

Н. Я. Мельничук, Я. В. Геник

Національний лісотехнічний університет Украӥни, м. Львів, Украӥна

\title{
ТОПОКЛІМАТИЧНІ ОСОБЛИВОСТІ САДОВО-ПАРКОВИХ КОМПОЗИЦЙНИХ ГРУП У ПАРКАХ МІСТА ЛЬВОВА
}

\begin{abstract}
Проаналізовано історико-стильовий генезис урбанізованих ландшафтів і формування системи садово-паркових насаджень міста Львова. Досліджено вплив місцевих ландшафтних геосистем і геофізичних процесів у них на формування топокліматичних характеристик парків. З'ясовано еколого-біологічні відмінності та особливості формування просторових природних явищ у певній садово-парковій композиції. Встановлено, що вивчення топокліматичних відмінностей потрібно починати із розгляду потоків сонячної радіації, температури повітря та грунту, атмосферних опадів і вітру. Проаналізовано територіальні еколого-біологічні відмінності та особливості формування просторових природних явищ залежно від потоків речовини та енергії. Виявлено вузькі амплітуди температури в геокомплексах вершин, середини і підніжжя схилів, бар'єрний вплив на міграцію та місцеву трансформацію повітряних мас, що впливає на специфіку піднаметового фітоценозу. Охарактеризовано врахування топокліматичних характеристик для підвищення комфортності розвитку садово-паркових композиційних груп. Відзначено, що поверхня пагорбів разом з мереживом стежок, прокладених на схилах, піддається ерозії та потребує зменшення та регулювання рекреаційного навантаження. Окреслено негативні явища, які сукупно із віковим чинником та відсутністю належного агротехнічного догляду впливають на умови місцезростання та розвиток паркових насаджень.
\end{abstract}

Ключові слова: топоклімат; амплітуда; рельєф; фітоценоз; паркові насадження, урбанізований ландшафт.

Вступ. Особливість Львова - це велике розмаїття форм земної поверхні: пагорби, долини, рівнини, вали, яри, балки, скелі (Babichenko \& Zuzuka, 1998). Оцінка природних умов міста доповнюється характеристиками радіаційного стану - інсоляції, освітленості, температури, вологості, що зумовлено різною експозицією схилів і вітровим режимом (Horbunov, 2014). Вплив на ландшафтний комплекс зовнішнього чинника, зумовленого геофізичними явищами (метеорологічними, кліматичними, гідрологічними), які мають малий характерний масштаб часу, запускає механізм деякої перебудови системи зв'язків, спрямованої до відновлення його динамічної рівноваги (Sukachov, 1966).

Метою роботи є розгляд процесів формування ландшафтно-кліматичних відмінностей під впливом зовнішніх і внутрішніх ландшафтних чинників в умовах садово-паркових об'єктів Львова та їх обгрунтування на конкретних прикладах.

Постановка проблеми. Топокліматичні особливості території міських зелених зон із пересічним рельєфом досліджують 3 метою розуміння еколого-біологічних особливостей функціонування природного середовища, а також для пояснення формування різноманітних явищ у приземному шарі атмосфери та у лан- дшафтно-композиційних групах, пізнання яких збагачує знання процесів у природному довкіллі.

Радіаційні потоки розподіляються з великою швидкістю, трохи пізніше встановлюється поле температури і випаровування (Ogneva, 1967). Гідрологічні характеристики формуються у самому садово-парковому об'єкті, а не входять у нього як сонячна радіація, тому їхні значення зміщені в часі щодо зовнішніх потоків. Ще більшу інерційність мають параметри рослинного вкриття, грунтового покриву та, особливо, рельєфу, хоча окремі їхні характеристики змінюються досить швидко (Bokov \& Smirnov, 2009; Horbunov, 2014).

Матеріали та методика дослідження. Дослідження мікроклімату різних підстильних поверхонь паркових насаджень Львова проводять щорічно науковці Національного лісотехнічного університету України із використанням аспіраційних психрометрів, термографів та актинометричних приладів (люксметри, піранометри та актинометри) (Melnychuk, 2003).

Здійснюючи попереднє обстеження території парків Львова маршрутним методом, увагу зосереджували на дванадцяти композиційних ділянках різного характеру розміщення. Для цього аналізували особливості природно-мікрокліматичних умов кожної ділянки (топоклі-

\section{Інформація про авторів:}

Мельничук Назар Ярославович, аспірант, кафедра ландшафтної архітектури та садово-паркового господарства. Email: yarhenyk@gmail.com

Геник Ярослав Вячеславович, д-р с.-г. наук, професор, завідувач кафедри ландшафтної архітектури та садово-паркового господарства. Email: yarhenyk@gmail.com; https://orcid.org/0000-0002-6079-6827

Цитування за ДСту: Мельничук Н. Я., Геник Я. В. Топокліматичні особливості садово-паркових композиційних груп у парках міста Львова. Науковий вісник НЛтУ України. 2019, т. 29, № 7. С. 108-111.

Citation APA: Melnychuk, N. Ya., Henyk, Ya. V. (2019). Topoclimatic Features of Garden-Parking Common Groups in the Park of the City of Lviv. Scientific Bulletin of UNFU, 29(7), 108-111. https://doi.org/10.15421/40290721 
мат) на підставі синхронних реєстрацій параметрів температури повітря на вершинах, середині та підніжжях пагорбів, балок і ярів на різних експозиціях ії розташування, з інтервалом 15 хв. Синхронні вимірювання проводили за стійкої літньої антициклональної погоди у липні-серпні під наметом дерев різного видового складу та на відкритих ділянках. Мікрокліматичні спостереження виконували згідно із загальноприйнятими методиками (Shcherban, 1968). Результати аналізу виміряних топокліматичних показників доповнювали спостереженнями, задокументованими стрічками самописців.

Для садово-паркових композицій груп враховували чинники їх еколого-біологічного співіснування у природних умовах. Історичні дані щодо розвитку паркових насаджень брали із літературних джерел та іконографічних матеріалів.

Виклад основного матеріалу. Місцевості парків 3 розчленованим рельєфом надзвичайно важливі у функціональному аспекті, оскільки саме тут відбуваються найінтенсивніші ландшафтно-геофізичні (аеро-, гідро-, педо- та біотичні) процеси, пов'язані з трансформацією температури та вологості повітря, міграцією приземних атмосферних потоків повітря, 3 модифікацією їхнього радіаційного, теплового та водного балансів, зокрема 3 формуванням складного режиму конденсації вологи, снігового перенесення та 3 адіабатичними трансформаціями (Mylkov, 1982; Horbunov, 2014).

Дослідженнями охоплено частини міських зелених територій з пересічним рельєфом, які півколом охоплюють східний край Львівської улоговини (Високий замок - Шевченківський гай - "Залізна вода" - Стрийський парк) (Koynov, 1964).

Парк "Високий Замок", який закладено у 1838 р., завдяки своєрідності природного та штучного рельєфу, складається 3 двох терас: нижньої - лежить на уступах Замкової і колишньої Княжої гори та верхньої - лежить під штучно зведеним конусом-кібцем. 3 низу аж до самої вершини тягнеться спіралеподібна паркова композиційна вісь, яка дає можливість оглядати панорами Львова. На схилах гори ростуть різні види дерев - каштани, клени, явори, ясени, буки. Під наметом деревостану парку дуже рідкий підріст і підлісок, місцями відсутне трав'яне вкриття. Незважаючи на проведений значний обсяг робіт із закріплення схилів парку, процес грунтової ерозії і досі відчутний (Kucheriavyi, 1981, 1991).

Лісопарк Шевченківський гай (стара назва - Кайзервальд), територія якого становить понад 80 га, характеризується пересічним рельєфом місцевості, що дало змогу створити найдивовижніші елементи паркової композиції. Лісопарк має поліфункціональне призначення та включає дендропарк, Шевченківський меморіальний комплекс і музей народної архітектури та побуту західних областей України (Kucheriavyi, 1981, 1991).

Стрийський парк належить до важливих внутрішньоміських парків і $\epsilon$ пам'яткою садово-паркового мистецтва національного значення. Парк складається 3 трьох ландшафтних частин: зона нижніх партерів - дно балки; лісопаркова зона - схили балки та верхня тераса. Стрийський парк характеризується значним різноманіттям аборигенних і інтродукованих деревних видів рослин (Kucheriavyi, 1981, 1991).
Парк "Залізна вода", який закладено у 1905 р. на схилах яру Полтви, характеризується пересіченим рельєфом місцевості. Хвилясті узгір'я та плато дозволили створити неповторний зелений острівець серед міської забудови центральної частини Львова. Природний деревостан парку представлений буковими насадженнями. Посеред масиву зелені зберігся старий яблуневий сад (Kucheriavyi, 1981).

Важливе екологічне значення досліджуваних парків має спектр належності видів до різних ценотичних систем - рослинних угруповань різного типу: лісові, лучні, гігрофільні та рудеральні (Kucheriavyi, 1991).

Встановлення еколого-біологічних відмінностей та особливостей формування просторових природних явищ у певній садово-парковій композиції потрібно починати з розгляду потоків сонячної радіації, температури повітря та грунту, атмосферних опадів, вітру тощо.

Інсоляція - чинник, який не рівномірно розподіляється по земній поверхні в умовах сильно пересіченого рельєфу. Відмінності між схилами різних експозицій, особливо між північними та південними, є істотними (Ogneva, 1967).

Розподіл атмосферних опадів незначно залежить від локальних форм рельєфу і локальних ландшафтів. Але краплі дощу, що падають на поверхню землі при вітрі, відхиляються та проектуються більшою мірою на навітряні схили (Shcherban, 1968). У Львові дощові опади переважають при вітрах західного та північно-західного напрямків, тобто західний сектор пагорба отримує опадів більше. Ефект заметільного перенесення снігу, який трапляється найчастіше при північно-східних вітрах сприяє накопиченню на західних схилах додаткової кількості вологи, що позитивно впливає на деревну рослинність (Andrianov, 1951).

Розподіл температури відображає розподіл прямої сонячної радіації, але контрасти частково згладжуються через перенесення тепла вітровими потоками. Відмінності кліматичних елементів відображаються в особливостях грунтового покриву та флористичного складу фітоценозів того чи іншого схилу.

Найбільш загальним початковим чинником, який повсюдно спричиняє відмінності схилів різних експозицій, є нерівномірне надходження сонячної радіації (інсоляція). Цей чинник має майже планетарний характер і зумовлює ланцюг подій, який є причиною відмінностей у радіаційному і водно-тепловому режимах схилів, геоморфологічних процесах, грунтовому покриві та рослинному вкритті (Ogneva, 1967).

Отже, погодно-кліматичні відмінності у схилових садово-паркових композиціях насамперед пов'язані 3 просторовою неоднорідністю інсоляційних, теплобалансових, воднобалансових чинників та вітрових потоків. Сукупність усіх чинників призводить до відмінностей еколого-біологічних процесів, які відбуваються на різних схилах парків. Найістотніші різкі відмінності пов'язані зі схилами південної та північної експозицій.

За методикою мікрокліматичних розрахунків (Shcherban, 1968) встановлено, що відмінності між південними та північними схилами крутістю $20^{\circ}$ становлять у січні $70 \%$, а в липні - $20 \%$. С також відмінності і між східними та західними схилами. Вони пов'язані 3 добовим ходом хмарності: влітку конвективні хмари 
(найпоширеніші в денний час) розвиваються найчастіше після полудня, а взимку хмарність вища до полудня (Melnychuk, 2003).

Формування погодно-кліматичних відмінностей між схилами західної та східної експозицій пояснюють особливим характером структури теплового балансу. T. А. Огнєва (Ogneva, 1967) довела, що після зміни знака радіаційного балансу в ранні ранкові години основна кількість радіаційної енергії перетворюється в тонкому шарі діяльної поверхні в тепло і витрачається на прогрівання грунту та на нагрівання приземного шару повітря. Тільки після зменшення вертикальних градієнтів температури у грунті та у повітрі починається процес випаровування, який найбільших значень досягає у післяполудневі та вечірні години. Таке співвідношення складників теплового балансу має принципове значення для формування умов зволоження на схилах різної експозиції. Виявлено, що температура повітря в першій половині дня в долині парків на $2-3{ }^{\circ} \mathrm{C}$ вища, а в середині та у другій половині дня на $1-2{ }^{\circ} \mathrm{C}$ нижча, ніж на прилеглих схилах і вершинах.

Відмінності у надходженні інсоляційних потоків визначають значну різницю у зволоженні схилів, що сприяє формуванню певного флористичного складу фітоценозів на схилах різних експозицій. Класичним прикладом є глибоко врізана балка у Стрийському парку - найбільш заліснені схили північно-західної та західної експозицій, які й характеризуються вологішими умовами.

На заліснених схилах, де добре виражена підстилка, поверхневий стік виникає тільки при сильних зливах, а ерозійні процеси $є$ менш вираженими. Потужні водні потоки від злив зносять родючий верхній шар грунту зверху вниз і акумулюють його у нижній частині схилу, де простежується збільшення потужності грунтових розрізів і потужності гумусового горизонту вниз по схилу. Результатом цього є відмінності у видовому складі рослинного вкриття у верхній і нижній частинах схилів парків.

Відмінності між схилами різних експозицій не завжди є істотними. Це пояснюють ефектом затінення схилів сусідніми формами рельєфу, різними насадженнями чи спорудами. Особливо затінення проявляється у нижніх частинах схилів південної, південно-західної та південно-східної експозицій глибоко врізаних долин - парки Високий Замок і Залізна вода, менше у Стрийському парку.

Висновки. Територіальні еколого-біологічні відмінності та особливості формування просторових природ- них явищ в умовах садово-паркових об'єктів в межах локальних схилів зумовлені просторовою неоднорідністю радіаційного та теплового балансів, перерозподілом снігу, вітровими потоками, проекцією крапель дощу. Ці відмінності визначають особливості формування рослинного вкриття та грунтового покриву на різних схилах парків Львова. Проведені дослідження наявних рослинних композицій парків Львова засвідчи значне біорізноманіття рослинного вкриття. Однак формування несприятливих умов зростання рослин на схилах різної експозиції, відсутність належного агротехнічного догляду, наступ рудеральної видів, самосіву та рясної порослі призводять до втрати декоративного вигляду та руйнування садово-паркових композиційних пейзажів паркових насаджень міста Львова.

\section{Перелік використаних джерел}

Andrianov, M. S. (1951). Mikroklimaticheskiye osobennosti goroda Lvova. Geografichniy zbirnik LDU, 1, 93-100. [In Russian].

Babichenko, V. M., \& Zuzuka, F. V. (1998). Klimat Lvova. Lutsk: Publishing House Vol.DU, 187 p. [In Ukrainian].

Bokov, V A., \& Smirnov, V. O. (2009). Rol mestopolozheniy v landshaftnoy differentsiatsii Kryma. Yekosistemi Kryma, ikh optimizatsiya i okhrana, 13, 80-98. [In Russian].

Horbunov, R. V. (2014). Landshaftno-klimatychna dysymetriya skhylovykh lokalnykh landshafnykh kompleksiv hirskoho Krymu. Problemy hirskoho landshaftoznavstva, 1, 95-99. Simferopol: Tavriyskyy natsionalnyy universytet imeni V. I. Vernadskoho. [In Ukrainian].

Koynov, M. M. (1964). Prirodno-geograficheskiye landshafty okrestnostey g. Lvova. In Voprosy regiona i ge lnogo landshaftovedeniya omorfologii SSSR. Lviv, (pp. 54-64). [In Russian].

Kucheriavyi, V. P. (1981). Zelenaya zona goroda. Kyiv: Scientific thought, 248 p. [In Russian].

Kucheriavyi, V. P. (1991). Urboekolohiia. Lviv: Svit, 360 p. [In Ukrainian].

Melnychuk, S. P. (2003). Mikroklimat riznykh typiv pidstylayuchoyi poverkhni u m. Lvovi. Problemy urboekolohiyi, urbolandshaftoznavstva i fitomelioratsi: Materials of the International Conference. Lviv: UkrSFU, 7 p. [In Ukrainian].

Mylkov, F. N. (1982). Asymmetryya landshaftnykh kompleksov. Zemlevedenye, 15, 5-16. [In Russian].

Ogneva, T. A. (1967). Rol radiatsionnogo balansa v summarnom isparenii. Teplovoy balans. Tr. Glavnoy Geofiz. observat. im. V. I. Voyeykova, 193, 130-136. [In Russian].

Shcherban, M. I. (1968). Mikroklimatologiya. Kiev: Kiev University Publishing House, 212 p. [In Russian].

Sukachov, V. N. (1966). Osnovnyye ponyatiya o biogeotsenozakh i obshcheye napravleniye ikh izucheniya. Programma i metodika biogeotsenoticheskikh issledovaniy: sb. nauch. tr., 7-19. Moscow: Science. [In Russian].

N. Ya. Melnychuk, Ya. V. Henyk

Ukrainian National Forestry University, Lviv, Ukraine

\section{TOPOCLIMATIC FEATURES OF GARDEN-PARKING COMMON GROUPS} IN THE PARK OF THE CITY OF LVIV

The ecological and biological features of development and the state of gardening stands in urban landscapes of the ancient city are studied. The historical-stylistic genesis of the urban landscapes and the formation of a system of landscape and garden plantations in Lviv are analyzed. Their phytocoenic features, in particular, floristic, spatial, and ecological and population structure, system organization, vitality are investigated and generalized. The influence of spatial structure of city plantations on their vitality and aesthetics is investigated. Urban features of urban degradation changes in parks plantations are studied. The influence of local landscape geosystems and geophysical processes in them on the formation of tocoplimatic characteristics of parks is researched. The ecological and biological differences and peculiarities of the formation of spatial natural phenomena in a certain garden-park composition are elucidated. It has been established that the study of tocoplimatic differences should begin with consideration of solar 
radiation fluxes, air and soil temperatures, atmospheric precipitation, wind, etc. The influence of physical and geographic factors on the formation of sloping local garden-park composition groups in terms of revealing patterns of formation of their structure and functioning is evaluated. The analysis of territorial ecological and biological differences and special features of the formation of spatial natural phenomena in connection with certain fields and flows of matter and energy has been carried out. The narrow amplitudes of temperature in the geocomplexes of vertices, the middle and the bottom of slopes, the barrier effect on migration and the local transformation of air masses, which affects the specificity of subnatural phytocoenosis, have been revealed. The authors have characterized paying special attention to the top-climatic characteristics for increasing the comfort of development of gardenpark composition groups. It is noted that the surface of the hills along with the lace paths laid on the slopes undergoes erosion and requires reduction of recreational load. The negative phenomena are outlined, which, together with the age factor and the lack of proper agrotechnical care, affect the conditions of the location of plantings. The ways of phytomeliorative optimization of the efficiency of gardens and parks of the complex green zone of the city are substantiated.

Keywords: tocoplimat; amplitude; relief; phytocoenosis; park plantations, urbanized landscape. 